\title{
Roman Malarz
}

Uniwersytet Pedagogiczny

im. Komisji Edukacji Narodowej

w Krakowie

\section{Terytorialne pochodzenie kandydatów na studia z turystyki i rekreacji w Uniwersytecie Pedagogicznym w Krakowie}

W roku 2011 Uniwersytet Pedagogiczny im. Komisji Edukacji Narodowej w Krakowie obchodzić będzie 65 rocznicę swej działalności. Początkowo pod szyldem Wyższej Szkoły Pedagogicznej, a później Akademii Pedagogicznej w uczelni kształcili się przyszli nauczyciele, a także studenci kierunków nienauczycielskich. W rozpoczynającym się jubileuszowym roku akademickim w UP w Krakowie funkcjonowało 25 kierunków studiów stacjonarnych i prawie tyle samo niestacjonarnych. Uczelnia kształci na wszystkich trzech poziomach studiów: licencjackim (studia pierwszego stopnia), magisterskim (drugiego stopnia) i doktoranckim (trzeciego stopnia). Uniwersytet Pedagogiczny dzięki wysokim pozycjom w rankingach szkół wyższych w Polsce i dobrej bazie lokalowej cieszy się dużą popularnością wśród kandydatów na studia. Od kilku lat na pierwszy rok studiów w UP przyjmuje się ponad 2500 studentów na studia stacjonarne I stopnia (ryc. 1). W roku 2010 na studia stacjonarne pierwszego stopnia przyjęto 2885 studentów. Do tego doliczyć należy ponad 200 studentów, którzy podjęli studia II stopnia oraz 784 studentów, którzy podjęli studia w systemie niestacjonarnym (711 na studiach I stopnia i 73 na studiach II stopnia). Łącznie ze studentami studiów doktoranckich studia w UP rozpoczęło w 2010 r. prawie 3900 osób.

Ryc. 1. Liczba studentów przyjętych na studia stacjonarne I stopnia w Uniwersytecie Pedagogicznym w Krakowie w wybranych latach.

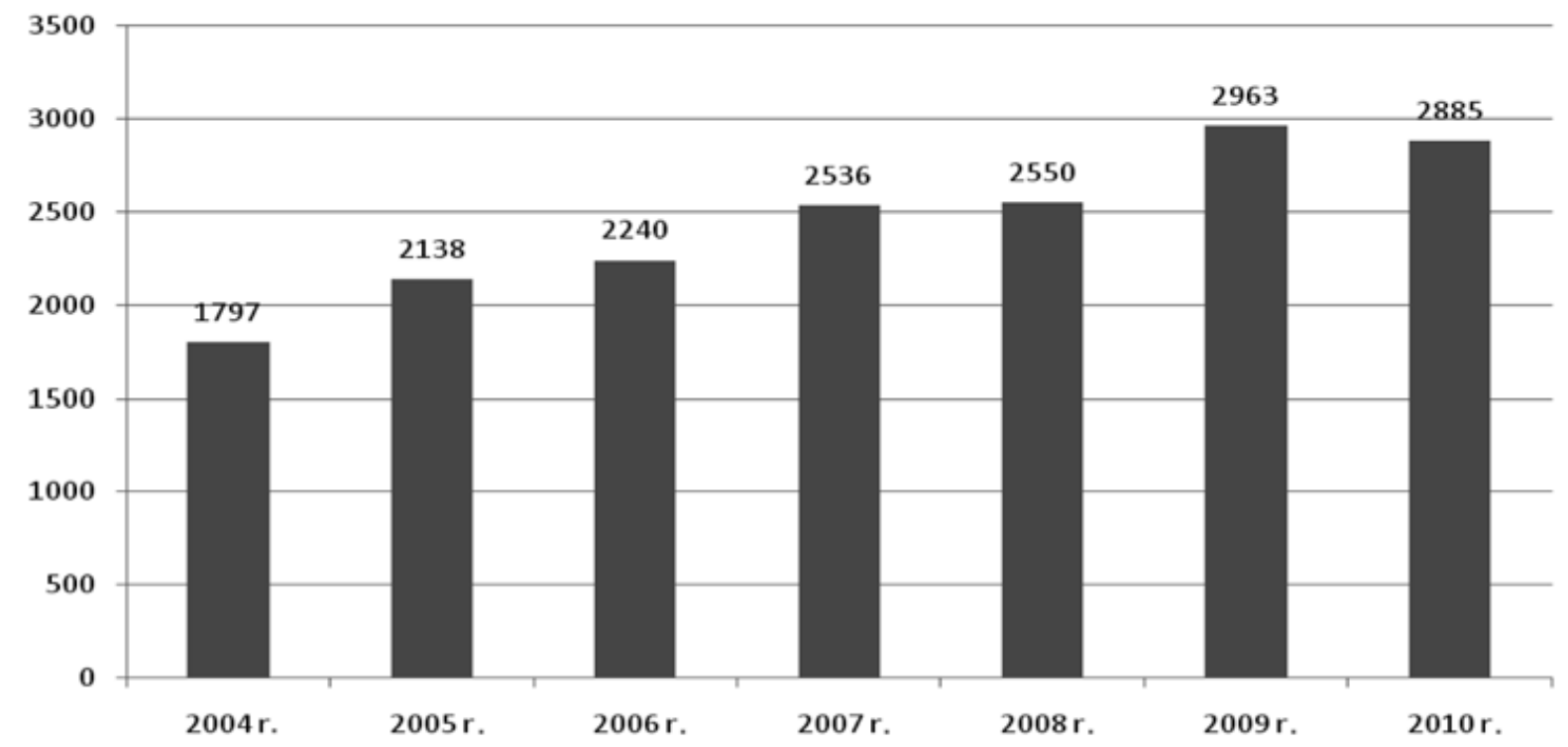

Źródło: materiały niepublikowane Uczelnianej Komisji Rekrutacyjnej UP w Krakowie. 
Ryc. 2. Liczba osób przyjętych na pierwszy rok studiów stacjonarnych (s) i niestacjonarnych (n) w Uniwersytecie Pedagogicznym w Krakowie w 2010 r.

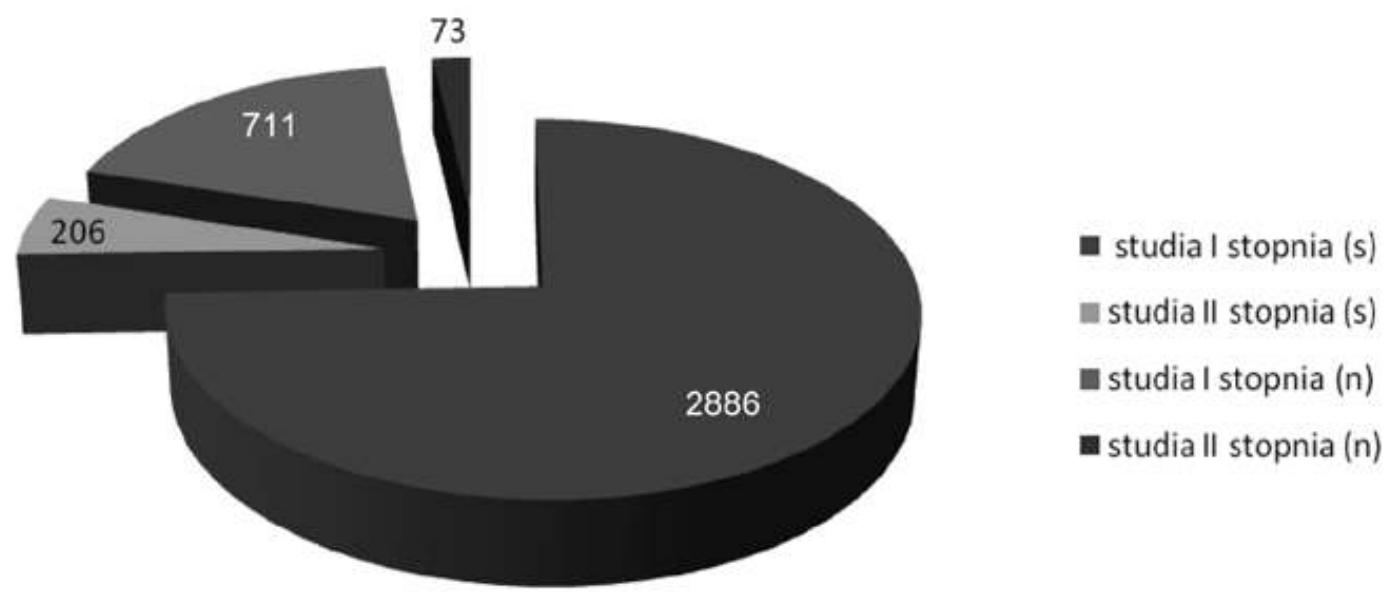

Źródło: materiały niepublikowane Uczelnianej Komisji Rekrutacyjnej UP w Krakowie.

\section{Popularność kierunków studiów}

Spośród 24 kierunków oferowanych kandydatom nie wszystkie cieszyły się jednakową popularnością. W roku 2010 największa liczba kandydatów zgłosiła się na pedagogikę przedszkolną i wczesnoszkolną, turystykę i rekreację oraz na filologię polską (tab. 1). Niewielka liczba chętnych, znacznie poniżej limitu, chciała studiować fizykę oraz filologię rosyjską z językiem rusińsko-łemkowskim. Uwzględniając liczbę miejsc na poszczególnych kierunkach, liczba kandydatów przypadających na jedno miejsce wahała się od 17,76 na filologii angielskiej do 0,18 na fizyce.

Tab. 1. Najpopularniejsze kierunki studiów I stopnia w UP w Krakowie w roku 2010

\begin{tabular}{|c|l|c|c|c|}
\hline Lp. & \multicolumn{1}{|c|}{ Kierunek studiów - specjalność } & $\begin{array}{c}\text { Liczba } \\
\text { kandydatów }\end{array}$ & Limit miejsc & $\begin{array}{c}\text { Średnio } \\
\text { na jedno } \\
\text { miejsce }\end{array}$ \\
\hline 1 & $\begin{array}{l}\text { Pedagogika; specjalność - przedszkolna } \\
\text { i wczesnoszkolna }\end{array}$ & 855 & 50 & 17,10 \\
\hline 2 & Turystyka i rekreacja & 789 & 100 & 7,88 \\
\hline 3 & Filologia polska & 739 & 240 & 3,08 \\
\hline 4 & Administracja & 706 & 60 & 11,76 \\
\hline 5 & Stosunki międzynarodowe & 618 & 60 & 10,30 \\
\hline 6 & Bezpieczeństwo narodowe & 558 & 60 & 9,30 \\
\hline 7 & Filologia angielska - nauczycielska & 533 & 45 & 11,84 \\
\hline 8 & Filologia angielska - nienauczycielska & 411 & 25 & 17,76 \\
\hline 9 & Socjologia & 384 & 90 & 4,57 \\
\hline 10 & $\begin{array}{l}\text { Pedagogika; } \\
\text { specjalność - społeczno-opiekuńcza }\end{array}$ & 100 & 3,84 \\
\hline
\end{tabular}

Źródło: materiały niepublikowane Uczelnianej Komisji Rekrutacyjnej UP w Krakowie. 


\section{Studia z turystyki i rekreacji}

Opracowania bogatych materiałów statystycznych znajdujących się w dyspozycji komisji rekrutacyjnych mają wieloletnią historię i bogatą literaturę (Długosz 1987, 1977; Jakóbczyk-Gryszkiewicz, Włodarczyk 1995; Jażdzewska, Wolaniuk 1996). Także Wydziałowa Komisja Rekrutacyjna pracująca w UP w Krakowie włączyła się w ten nurt badań (Malarz i inni 2009). Rok 2010 był drugim z kolei rokiem, w którym prowadzono rekrutację na studia z turystyki i rekreacji. W porównaniu z rokiem poprzednim liczba kandydatów na studia stacjonarne pierwszego stopnia spadła z 1022 (2009 r.) do 789 (2010 r.). Spadek ten był dość znaczny, gdyż wynosił $26 \%$. Tłumaczyć go mogą co najmniej trzy przyczyny. Po pierwsze, spadek urodzeń w latach 1984-2004 powoduje, że coraz mniej liczne roczniki docierają do matury. W roku 2010 maturę zdawali kandydaci urodzeni w większości w roku 1992. W roku tym urodziło się w Polsce o 6\% mniej dzieci niż w poprzednim, 1991 r. (Szymańczak 1998, Szkolnictwo 2009). W liczbach bezwzględnych wielkości te kształtowały się następująco: 547,7 tys. w roku 1991 i 515, 2 tys. w roku 1992. Ten spadek to pierwsza przyczyna mniejszej liczby kandydatów.

Drugą niezwykle ważną przyczyną była informacja o wysokich wymaganiach stawianych kandydatom przez Wydziałową Komisję Rekrutacyjną. W roku 2009 przyjmowano na studia stacjonarne z turystyki i rekreacji kandydatów, których średnia z przedmiotów zapisanych na świadectwie maturalnym przekraczała $90 \%$. Wiadomość ta nie stanowiła tajemnicy i zapewne dotarła do kandydatów, którzy w roku następnym chcieli podjąć starania o przyjęcie na studia. Wielu z nich, mając nie najlepsze świadectwa maturalne, zniechęciła do starań o przyjęcie na turystykę i rekreację. Potwierdzeniem tej tezy może być znaczny spadek kandydatów z Krakowa.

Trzecią, zdaniem autora najmniej ważną, przyczyną był nieznaczny spadek skolaryzacji rocznika 1992 w stosunku do rocznika 1991. Jednak jego wielkość raczej nie zdecydowała o spadku liczby kandydatów na studia w 2010 r. Z dużym zainteresowaniem śledzić należy liczbę kandydatów na ten kierunek studiów w następnych latach.

\section{Terytorialne pochodzenie kandydatów}

Podobnie jak w roku 2009, tak i w roku 2010 dominującą grupę stanowili kandydaci z Małopolski (bez Krakowa). Ich udział procentowy w ogólnej liczbie kandydatów wzrósł z 36,3\% w roku 2009 do 43,5\% w roku 2010 (tab. 2). Zmalał nieco udział kandydatów podających Kraków jako miejsce zamieszkania. Nadal jednak Małopolska, łącznie z Krakowem, jest województwem, $z$ którego rekrutuje się ponad 65\% kandydatów (tab. 2).

$\mathrm{Z}$ województw ościennych najwięcej kandydatów pochodziło $\mathrm{z}$ województwa śląskiego. Odsetek kandydatów z tego województwa wzrósł z 10,2\% (2009 r.) do 12,7\% (2010 r.). Województwo śląskie uplasowało się na drugim miejscu po województwie małopolskim. W roku poprzednim miejsce to zajmowało województwo podkarpackie. Spadek województwa podkarpackiego na miejsce trzecie spowodowany jest zapewne uruchomieniem tego kierunku na państwowych i prywatnych uczelniach Rzeszowa i innych miast tego regionu. W roku akademickim 2009/2010 w województwie podkarpackim funkcjonowało siedem państw i trzy prywatne uczelnie, na których kształcili się studenci na kierunku turystyka i rekreacja (Długosz, Biały 2011). Miejsce czwarte, podobnie jak w roku poprzednim, zajmuje województwo świętokrzyskie. Jego udział wzrósł z 5,2\% w roku 2009 do 7,6\% w roku 2010. W województwie tym istnieje tylko jedna państwowa i trzy prywatne uczelnie, na których prowadzi się kształcenie na kierunku turystyka i rekreacja. Odnotowano natomiast spadek kandydatów pochodzących z województwa lubelskiego: z 3,7\% do $1,9 \%$. Województwo to nadal jednak zajmuje piąte miejsce wśród województw, z których pochodzi najwięcej kandydatów na studia z turystyki i rekreacji. Pozostałe województwa mają nieznaczny udział w dostarczaniu kandydatów 
na omawiany kierunek studiów. Zdziwienie wywołuje natomiast fakt, że podobnie jak w poprzednim roku, tak i w roku $2010 \mathrm{z}$ województwa kujawsko-pomorskiego nie pojawił się ani jeden kandydat.

Tab. 2. Terytorialne pochodzenie kandydatów na studia z turystyki i rekreacji (licencjackie, stacjonarne) w latach 2009 i 2010.

\begin{tabular}{|c|c|c|c|c|}
\hline \multirow[b]{2}{*}{ Województwo } & \multicolumn{2}{|c|}{ Rok 2010} & \multicolumn{2}{|c|}{ Rok 2009} \\
\hline & $\begin{array}{c}\text { liczba } \\
\text { kandydatów }\end{array}$ & $\begin{array}{c}\text { udzial } \\
\text { procentowy }\end{array}$ & $\begin{array}{c}\text { liczba } \\
\text { kandydatów }\end{array}$ & $\begin{array}{c}\text { udzial } \\
\text { procentowy }\end{array}$ \\
\hline małopolskie (bez Krakowa) & 337 & 43,5 & 365 & 36,3 \\
\hline Kraków & 174 & 22,3 & 301 & 30,0 \\
\hline śląskie & 99 & 12,7 & 103 & 10,2 \\
\hline podkarpackie & 76 & 9,8 & 117 & 11,6 \\
\hline świętokrzyskie & 59 & 7,6 & 52 & 5,2 \\
\hline lubelskie & 15 & 1,9 & 31 & 3,1 \\
\hline łódzkie & 7 & 0,9 & 12 & 1,2 \\
\hline mazowieckie & 4 & 0,5 & 9 & 0,9 \\
\hline wielkopolskie & 3 & 0,4 & 4 & 0,4 \\
\hline dolnośląskie & 3 & 0,4 & 2 & 0,2 \\
\hline opolskie & 3 & 0,4 & 1 & 0,1 \\
\hline warmińsko-mazurskie & 2 & 0,3 & 2 & 0,2 \\
\hline zachodniopomorskie & 2 & 0,3 & 2 & 0,2 \\
\hline podlaskie & 2 & 0,3 & 2 & 0,2 \\
\hline pomorskie & 1 & 0,1 & 2 & 0,2 \\
\hline kujawsko-pomorskie & 0 & 0 & 0 & 0 \\
\hline
\end{tabular}

Pogrubioną czcionką zaznaczono udziały procentowe z 2010 roku, których wielkość wzrosła w stosunku do roku poprzedniego.

Źródło: Opracowanie własne na podstawie materiałów Wydziałowej Komisji Rekrutacyjnej z lat 2009 i 2010.

\section{Kandydaci z Małopolski}

Województwo małopolskie łącznie z Krakowem to obszar, skąd pochodzi ponad 65\% kandydatów na studia z turystyki i rekreacji. Wydało się godnym uwagi prześledzenie, z których regionów województwa pochodzi najwięcej kandydatów. Aby to wykazać, skonstruowano wskaźnik, w którym podano, ilu mieszkańców danej jednostki terytorialnej przypada na jednego kandydata na omawiany kierunek Uniwersytetu Pedagogicznego w Krakowie. Wyliczenia te zawarto w czwartej i ósmej kolumnie tabeli 3. Generalnym wnioskiem płynącym z tej tabeli jest dość wyraźna zależność pomiędzy odległością Uniwersytetu Pedagogicznego od miejsca 
zamieszkania a liczbą kandydatów. Stąd najlepsze wskaźniki mają: Kraków oraz powiaty krakowski i wielicki (tab. 4). Jeden kandydat przypada tam na poniżej 5 tys. mieszkańców. Grupę drugą (od 5 do 10 tys. na jednego kandydata) stanowią powiaty nieco dalej oddalone od Krakowa. Grupę trzecią (ponad 10 tys. mieszkańców na jednego kandydata) tworzą powiaty nadgraniczne Małopolski (nowotarski, dąbrowski, miechowski, oświęcimski, chrzanowski). Wyjątkiem od tej reguły jest powiat tarnowski zajmujący ostatnie miejsce w tej klasyfikacji, niezbyt oddalony od UP i nieźle skomunikowany (łatwy dojazd) z Krakowem.

Tab. 3. Liczba kandydatów na studia z turystyki i rekreacji z Małopolski w rozbiciu na powiaty i miasta na prawach powiatów.

\begin{tabular}{|c|c|c|c|c|c|c|c|}
\hline Powiat & $\begin{array}{c}\text { Liczba } \\
\text { ludności }\end{array}$ & $\begin{array}{c}\text { Liczba } \\
\text { kand. }\end{array}$ & Wskaźnik & Powiat & $\begin{array}{c}\text { Liczba } \\
\text { ludności }\end{array}$ & $\begin{array}{c}\text { Liczba } \\
\text { kand. }\end{array}$ & Wskaźnik \\
\hline krakowski & 251836 & 69 & 3650 & myślenicki & 116484 & 14 & 8321 \\
\hline wielicki & 108767 & 26 & 4183 & N. Sącz & 84556 & 10 & 8455 \\
\hline m. Kraków & 755000 & 174 & 4339 & Tarnów & 115158 & 13 & 8858 \\
\hline tatrzański & 65362 & 13 & 5028 & nowotarski & 180987 & 18 & 10055 \\
\hline bocheński & 100160 & 19 & 5272 & proszowicki & 43561 & 4 & 10890 \\
\hline olkuski & 114426 & 17 & 6731 & dąbrowski & 58562 & 5 & 11712 \\
\hline suski & 81885 & 12 & 6824 & nowosądecki & 202044 & 16 & 12628 \\
\hline brzeski & 90967 & 13 & 6997 & miechowski & 50577 & 4 & 12644 \\
\hline wadowicki & 155923 & 22 & 7087 & oświęcimski & 153352 & 9 & 17039 \\
\hline limanowski & 121153 & 17 & 7127 & chrzanowski & 127660 & 7 & 18237 \\
\hline gorlicki & 107017 & 13 & 8232 & tarnowski & 195037 & 7 & 27862 \\
\hline
\end{tabular}

Źródło: Opracowanie własne na podstawie danych z Wydziałowej Komisji Rekrutacyjnej UP w Krakowie oraz Rocznika statystycznego Małopolski 2009.

Pozytywnym zaskoczeniem jest natomiast wysoka pozycja powiatu tatrzańskiego. Pochodzi stąd 13 kandydatów, co przy niewielkiej liczbie mieszkańców lokuje ten region na wysokiej, czwartej pozycji (tab. 4).

\section{Wieś i miasto}

Województwa Polski południowo-wschodniej, skąd pochodzi ponad 80\% kandydatów na turystykę i rekreację, charakteryzują się najmniejszym stopniem urbanizacji. W Małopolsce, na Podkarpaciu i w Świętokrzyskim większość mieszkańców mieszka na wsi. Rzutować to powinno na proporcje $\mathrm{w}$ udziale kandydatów ze wsi i z miast. Tymczasem $\mathrm{z}$ każdego $\mathrm{z}$ analizowanych województw młodzież wiejska nie stanowi większości (tab. 3). Przewaga kandydatów z miast jest w niektórych przypadkach ogromna (łódzkie, lubelskie, śląskie). Młodzież wiejska znacznie rzadziej niż młodzież miejska podejmuje próby dostania się na studia. Przyczyn tego faktu szukać należy w znacznie niższym wskaźniku skolaryzacji ponadgimnazjalnej młodzieży wiejskiej. Na ten dyskryminujący społeczeństwo wiejskie proces zwracało uwagę wielu autorów (Szulc 2000). 
Tab. 4. Udział kandydatów z miasta i wsi z województw, z których pochodziło najwięcej kandydatów na studia z turystyki i rekreacji w UP w Krakowie w roku 2010

\begin{tabular}{|c|c|c|c|c|}
\hline Województwo & Miasto & Udzial (\%) & Wieś & Udzial (\%) \\
\hline małopolskie (z Krakowem) & 285 & 57,2 & 213 & 42,8 \\
\hline śląskie & 68 & 68,7 & 31 & 31,3 \\
\hline podkarpackie & 37 & 56,0 & 29 & 44,0 \\
\hline świętokrzyskie & 37 & 62,7 & 22 & 37,3 \\
\hline lubelskie & 10 & 71,4 & 4 & 28,6 \\
\hline łódzkie & 6 & 85,7 & 1 & 14,3 \\
\hline
\end{tabular}

Źródło: Opracowanie własne na podstawie materiałów danych z Wydziałowej Komisji Rekrutacyjnej UP w Krakowie.

Spośród osób przyjętych na I rok turystyki i rekreacji z miast pochodziło 69,3\%. To znacznie więcej niż wynosił udział młodzieży miejskiej wśród kandydatów z Małopolski i wszystkich województw ościennych. Oznacza to, że z miast pochodzili także lepsi kandydaci, legitymujący się większą przeciętną na świadectwie maturalnym. W tabeli 5 zestawiono liczbę kandydatów pochodzących z miast, z których co najmniej pięciu kandydatów ubiegało się o przyjęcie na studia z turystyki i rekreacji w Uniwersytecie Pedagogicznym. Takich miast było 24. Oczywiście dominującą pozycję zajmuje w tym zestawieniu Kraków, z którego pochodziło 174 kandydatów. Dwa następne miejsca zajmują miasta znajdujące się dziś w województwie śląskim: Bielsko-Biała i Częstochowa. W latach 70. XX w. były to miasta wojewódzkie, niezależne od Katowic, stolicy Śląska. Zdaniem autora, fakt wysokiego udziału kandydatów z Bielska-Białej i Częstochowy świadczyć może o większym szacunku dla środowiska akademickiego Krakowa niż Katowic. Ze stolicy Śląska kandydatów było dwóch i w tym zestawieniu ich nie ujęto.

Katowice to jedyna stolica województw ościennych, która nie znalazła się w zestawieniu (tab. 5). Z Kielc i Rzeszowa było po pięciu kandydatów, niewiele w porównaniu z bardziej odległymi: Zamościem (dziewięciu kandydatów) i Sandomierzem (dziewięciu kandydatów).

Zdziwienie budzić może brak w powyższym zestawieniu takich dużych miast Małopolski, jak Nowy Targ czy Oświęcim. W ubiegłym roku kandydatów z Oświęcimia było ośmiu, zaś z Nowego Targu był tylko jeden kandydat. Z listy miast, z których w roku 2009 było więcej niż pięciu kandydatów (Malarz 2009), na obecnej liście nie znalazły się jeszcze: Tarnobrzeg, Sanok, Rabka, Andrychów, Cieszyn, Jędrzejów, Myślenice i Radom. Pojawiły się natomiast miasta, które w roku poprzednim „dostarczyły” mniej niż pięciu kandydatów. Zdecydowaną progresję odnotowały: Wieliczka, Zakopane, Jordanów, Wadowice, Skarżysko-Kamienna i Czechowice-Dziedzice.

Interesujące wydawało się poddanie analizie maturalnych osiągnięć kandydatów. Zapisane są one w postaci procentowej przy każdym zdawanym na maturze przedmiocie. Średnia tych procentowych ocen była lub nie przepustką na studia. Najlepsze świadectwa mieli kandydaci z Tarnowa, Kielc, Olkusza i Zakopanego (ryc. 3, tab. 5). Najsłabszymi wynikami maturalnymi legitymowali się kandydaci z Wieliczki, Buska-Zdroju i Jordanowa. Maturzyści z Krakowa nie błyszczeli na tle innych miast. Średnia 72,1\% lokuje kandydatów ze stolicy Małopolski na 15 miejscu spośród 24 rozpatrywanych miast. 
Tab. 5. Miasta, skąd pochodziło najwięcej kandydatów wraz ze średnią ocen (w \%) z przedmiotów na świadectwie maturalnym

\begin{tabular}{|c|c|c|c|}
\hline Lp. & Miasto & $\begin{array}{c}\text { Liczba } \\
\text { kandydatów }\end{array}$ & $\begin{array}{c}\text { Średnia z przedmiotów } \\
\text { zapisanych na świadectwie }\end{array}$ \\
\hline 1 & Kraków & 174 & 72,1 \\
\hline 2 & Bielsko-Biała & 16 & 76,8 \\
\hline 3 & Częstochowa & 13 & 70,7 \\
\hline 4 & Tarnów & 12 & 83,9 \\
\hline 5 & Nowy Sącz & 10 & 71,4 \\
\hline 6 & Wieliczka & 10 & 67,6 \\
\hline 7 & Zamość & 9 & 75,9 \\
\hline 8 & Sandomierz & 9 & 74,3 \\
\hline 9 & Olkusz & 8 & 79,6 \\
\hline 10 & Mielec & 8 & 79,0 \\
\hline 11 & Skawina & 8 & 74,4 \\
\hline 12 & Bochnia & 8 & 69,0 \\
\hline 13 & Zakopane & 7 & 79,4 \\
\hline 14 & Skarżysko-Kamienna & 7 & 79,0 \\
\hline 15 & Jaworzno & 7 & 69,1 \\
\hline 16 & Czechowice-Dziedzice & 6 & 73,4 \\
\hline 17 & Gorlice & 6 & 67,9 \\
\hline 18 & Kielce & 5 & 83,2 \\
\hline 19 & Wadowice & 5 & 78,3 \\
\hline 20 & Dębica & 5 & 75,4 \\
\hline 21 & Przemyśl & 5 & 74,2 \\
\hline 22 & Rzeszów & 5 & 70,4 \\
\hline 23 & Busko-Zdrój & 5 & 66,2 \\
\hline 24 & Jordanów & 5 & 63,1 \\
\hline
\end{tabular}

Źródło: Opracowanie własne na podstawie materiałów danych z Wydziałowej Komisji Rekrutacyjnej UP w Krakowie. 
Ryc. 3. Średnie wyniki z matury kandydatów z wybranych miast

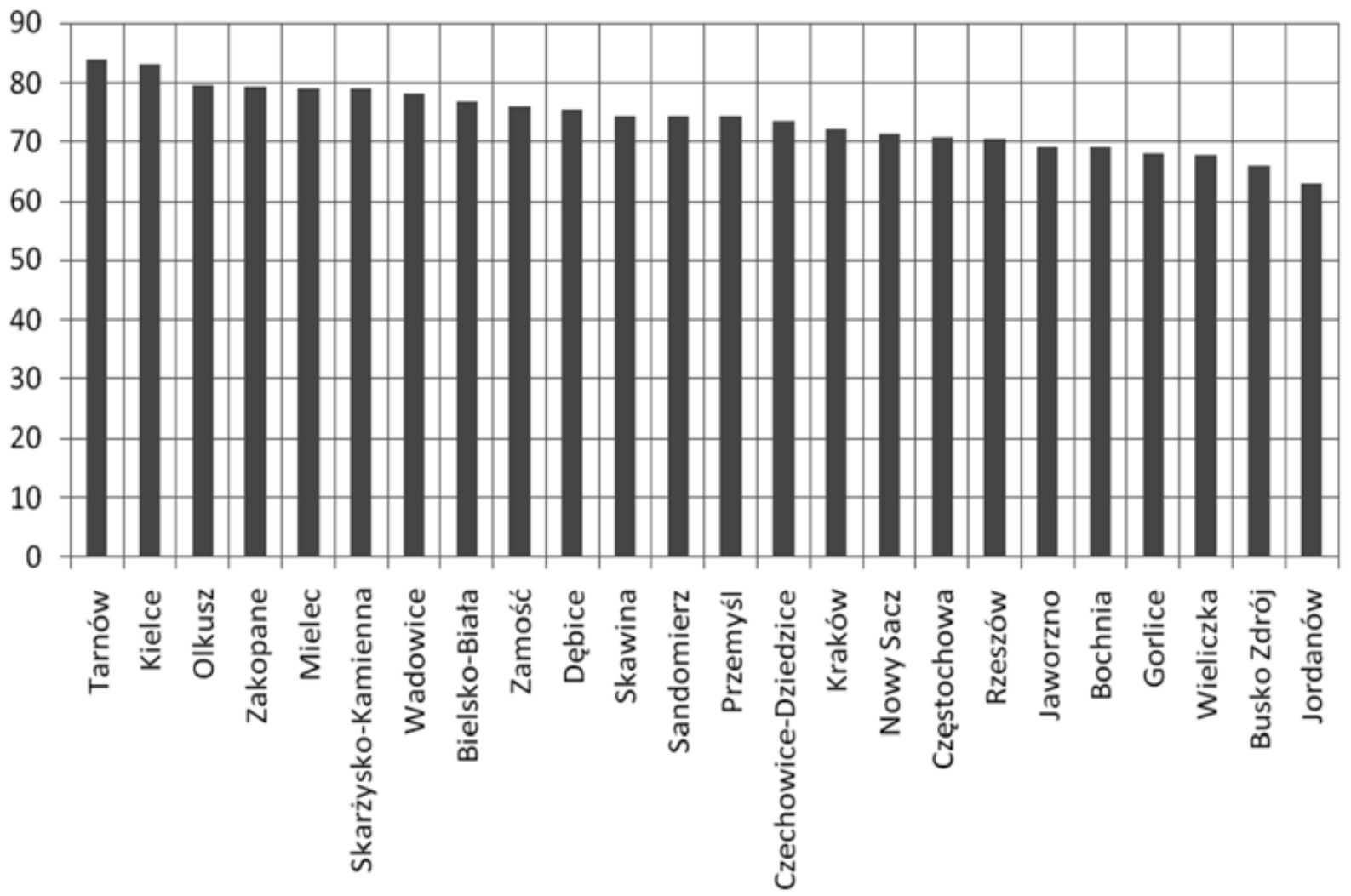

Źródło: Opracowanie własne na podstawie materiałów danych z Wydziałowej Komisji Rekrutacyjnej UP w Krakowie.

Zaprezentowane opracowanie jest kolejną analizą terytorialnego i społecznego pochodzenia kandydatów na studia z turystyki i rekreacji w Uniwersytecie Pedagogicznym w Krakowie. Autor starł się dociec, co było przyczyną spadku liczby kandydatów w stosunku do roku poprzedniego. Dwuletni okres badań zmian w terytorialnym pochodzeniu kandydatów jest zbyt krótki, aby doszukiwać się trwałych trendów i wyraźnych tendencji. Dopiero dalsze badania prowadzone w następnych latach pozwolą na wyciągnięcie prawidłowych wniosków z obfitego materiału statystycznego znajdującego się w dyspozycji Wydziałowej Komisji Rekrutacyjnej. Także badania ankietowe studentów przyjętych na pierwszy rok studiów z turystyki i rekreacji pozwolą poszerzyć wiadomości na tematy społeczne i socjologiczne (wielkość rodziny, status społeczny, wykształcenie i zatrudnienie rodziców, motywacje w wyborze kierunku studiów, oczekiwania i plany studentów). Wyniki takich badań przeprowadzonych na studentach I roku studiów stacjonarnych i niestacjonarnych zaprezentował autor w poprzednim opracowaniu (Malarz 2009).

\section{Literatura}

1. Długosz Z., 1977, Rekrutacja i wyniki egzaminów wstepnych na kierunek „geografia” Uniwersytetu Jagiellońskiego $w$ niektórych aspektach społeczno-przestrzennych, „Zeszyty Naukowe UJ. Prace Geograficzne", z. 44, 41-54.

2. Długosz Z., 1987, Rekrutacja i wyniki egzaminów wstępnych na kierunek geograficzny w Uniwersytecie Jagiellońskim w latach 1968-1985, „Zeszyty Naukowe UJ. Prace Geograficzne”, z. 70, 167-181. 
3. Długosz Z., Biały S., 2011, Studia w zakresie turystyki na tle szkolnictwa wyższego w kraju, Konferencja „Przedsiębiorczość w warunkach globalizacji” UP Kraków, październik 2010 (w druku).

4. Jakóbczyk-Gryszkiewicz J., Włodarczyk B., 1995, Charakterystyka kandydatów na studia z geografii turyzmu i hotelarstwa $w$ Uniwersytecie Lódzkim w roku akademickim 1994/95, „Turyzm”, t. 5, z. $1,84-88$.

5. Jażdżewska I., Wolaniuk A., 1996, Charakterystyka kandydatów na specjalność geografia turyzmu i hotelarstwa Uniwersytetu Łódzkiego w roku 1995, „Turyzm”, t. 6, z. 2, 121-126.

6. Malarz R., Rettinger R., Warcholik W., 2009, Preferencje młodzieży wiejskiej w wyborze kierunku studiów (na przykładzie Uniwersytetu Pedagogicznego w Krakowie), Wydawnictwo WSEiP, Kielce (w druku).

7. Malarz R., 2009, Charakterystyka kandydatów na studia z turystyki i rekreacji w Uniwersytecie Pedagogicznym w Krakowie (oddane do druku).

8. Prestiz, profesjonalizm, nowoczesność, 2009, folder reklamowy Uniwersytetu Pedagogicznego w Krakowie, Wyd. Naukowe. UP w Krakowie.

9. Rocznik statystyczny województwa małopolskiego 2009, Urząd Statystyczny w Krakowie, Kraków.

10. Szkolnictwo wyższe w Krakowie - perspektywy rozwoju w kontekście zmian demograficznych. Prognoza na lata 2009-2014, K. Jakubik (red.), Urząd Statystyczny w Krakowie, Kraków, listopad 2009.

11. Szulc T., 2000, Wyjść z wiejskiego kręgu niemocy, „Głos Uczelni”, nr 84, Wyd. Uniwersytetu Przyrodniczego we Wrocławiu, s. 16-24.

12. Szymańczak J., 1998, Zmiany demograficzne, „Studia Demograficzne”, nr 4/134, s. 8-14.

\section{Region-wise Distribution of Candidates for the Faculty of Tourism and Recreation at the Pedagogical University of Cracow}

2010 was the second year of recruitment for Tourism and Recreation studies at the Pedagogical University in Krakow. In 2009 as many as 1022 candidates applied for the full-time first stage studies at this faculty. In 2010 the number decreased by 26\% (789 candidates). Despite this decrease the faculty was still one of the most popular at the Pedagogical University, and in the ranking of the number of candidates took the second place. Candidates for Tourism and Recreation faculty in $65 \%$ originated from the Malopolskie voivodeship, including 22.3\% of candidates from Krakow. As compared to the previous year, the share of candidates from the capital of Malopolskie voivodeship decreased by a few per cent. A significant number of candidates originated from the surrounding voivodeships: the Silesian, Subcarpathian and Świętokrzyskie voivodeships. From amongst other voivodeships a significant number of candidates originated from the Lubelskie voivodeship. In the recruitment so far there were no candidates from Kuyavia and Pomerania voivodeship.

Most candidates from the Malopolskie voivodeship came from the nearest - Wielicki and Krakovian - poviats, whereas the fewest from the frontier regions (Nowotarski, Miechowski, Oswiecimski and Chrzanowski poviats). Most candidates were town inhabitants - over 69\% of the total candidates. There were as many as 24 towns with 5 candidates and more. The secondary school final examinations [Matura] results were also assessed. The best results were achieved by candidates from Tarnow, Kielce, Olkusz and Zakopane. The poorest results were achieved by candidates from Wieliczka, Busko Zdroj and Jordanow. A two-year cycle of research devoted to the candidates for tourism and recreation faculty reveals a considerable shift in the region-wise distribution of candidates for the faculty, however the period is too short to distinguish clear directions and trends in the shift. 